\title{
Initial growth of Jatropha curcas plants subjected to drought stress and silicon (Si) fertilization
}

\author{
Rosane Angélica Reis dos Anjos ${ }^{1}$, Lilian Cristina da Silva Santos ${ }^{1}$, Diego Braga de Oliveira ${ }^{1}$, Camila \\ Lariane Amaro ${ }^{1}$, Jovan Martins Rios ${ }^{1}$, Gabriela Teodoro Rocha ${ }^{1}$, Bruno Silva Melo ${ }^{1}$, Fábio Santos \\ Matos $^{* 2}$
}

\author{
${ }^{1}$ Post-Graduate Program in Plant Production of the State University of Goiás (UEG), Brazil \\ ${ }^{2}$ Graduate Program in Plant Production of UEG, Câmpus Ipameri, highway GO 330, Km 241, ring road, \\ university sector, 75780-000-Ipameri, GO, Brazil
}

*Corresponding author:fabio.agronomia@hotmail.com

\begin{abstract}
This study aimed to assess the effect of silicon fertilization on the growth of Jatropha curcas L. seedlings subjected to drought stress. The study was conducted in a greenhouse at the State University of Goiás on the Ipameri Campus, Goiás state, using eight-liter pots containing a substrate of red-yellow latosol, sand and manure at a ratio of 3:1:0.5, respectively. A completely randomized 5x2 factorial design was applied (plants irrigated every day with a water volume corresponding to $0,25,50,75$ and $100 \%$ evapotranspiration and foliar feeding of Si at concentrations of 0 and $1 \mathrm{~g} \mathrm{~L}^{-1}$, applied on April 29 and May 6, 2016, in a volume of 30 $\mathrm{ml} /$ plant/application), with four repetitions and a single genotype per pot. Drought stress treatment was imposed on April 29, 2016, when the plants were 60 days old, and lasted 13 days. Water availability directly affected plant growth. Regardless of Si dose, biomass accumulation, number of leaves, stem diameter and leaf area exhibited a linear decline proportional to the decrease in water supply. The reduction in the leaf mass ratio, number of leaves and leaf area occurs because water is needed to initiate and expand leaf primordia. The high stomatal sensitivity of Jatropha curcas combined with the reduced biomass partitioned among the leaves contributed to decreasing transpiration and maintaining water status. The Si doses did not alleviate the water shortage in Jatropha curcas plants. Jatropha curcas plants are drought tolerant and capable of delaying the dehydration of tissue and partitioning assimilates for root growth.
\end{abstract}

Received 18 Oct 2016; Revised 8 Jan 2017; Accepted 6 March 2017.

Keywords: Biofuel; petrodiesel; oleaginous plants; plant nutrition; renewable energy

Abbreviations: ETo_Reference evapotranspiration, RWC_Relative water content, BIO_biomass, SD_stem diameter, NL_number of leaves, LA_leaf area, Evap_evapotranspiration, $S i$ _ silicon, RMR_root mass ratio, LMR_leaf mass ratio, SMR_stem mass ratio, Chl $a \_$Chlorophyll $a$, (Chl $b \_$chlorophyll $b$, Chl $a+b \_l$ leaf concentration of chlorophyll $a+b$, CAR_carotenoids, $E_{-}$transpiration, Aw_wet tropical climate, $\mathrm{CaCO}_{3}$ calcium carbonate.

\section{Introduction}

The growth in the global demand for energy has prompted studies for viable alternatives to replace fossil fuels with renewable sources, such as biofuels, that have less impact on the environment. Brazil stands out for the high percentage of renewable sources (43\%) in its energy matrix and is currently the world's second largest producer of biodiesel, applying a mandatory $7 \%$ blend with petrodiesel across the country (National Agency of Petroleum - ANP, 2016).

Brazil's diverse climate, arable land and significant unexploited oil reserves mean the country has high biodiesel production potential. Promising species for biofuel production are gaining ground in the world economy (Carvalho et al., 2012). In this context, the Barbados nut (Jatropha curcas L.) emerges as an alternative raw material for the production of biodiesel due to the high oil content of its seeds and the physical and chemical characteristics of the oil (Matos et. al., 2010).

The Barbados nut is used by rural communities for a variety of purposes, including as a biofuel, since its seeds contain 30 to $40 \%$ oil, in soil conservation, and as a source of decomposed organic matter rich in nitrogen, phosphorous and potassium. Latex extracted from the stem and branches are used for pharmacological purposes (Openshaw, 2000; Ferreira et al., 2015). J. curcas is a perennial monoecious plant from the family Euphorbiaceae, which contains approximately 317 genera and 8,000 species (Dehgan and Webster, 1979). It grows well in dry tropical regions, humid equatorial zones, and arid, rocky terrain (Fao, 2010). The expansion of commercial exploitation requires the elucidation of basic agronomic aspects not yet available for the species, as well as the development of management techniques that ensure high yields.

Although tolerant to drought, when subject to water restrictions, the Barbados nut exhibits stunted growth, a decline in the number of fertilized flowers and reduced grain yield (Matos et al., 2010). The development of management techniques that ensure minimum growth even during periods of water scarcity could increase the productivity and 
profitability of the species. Foliar feeding with silicon ( $\mathrm{Si}$ ) in the Barbados nut and other species seems to play a decisive role in maintaining tissue hydration under drought stress and/or salinity (Bukhari et al., 2015; Carvalho Junior et al., 2014).

An adequate supply of Si can reduce transpiration by $30 \%$ in plant species with altered stomatal movement and cuticle thickness (Ma et al., 2001). Silicon applied to leaves forms silica bodies on epidermal cells, accumulating on organs involved in transpiration, improving water use efficiency and increasing drought resistance (Nwugo and Huerta, 2008). This element also increases antioxidant defenses and stomatal resistance (Gong et al., 2005; Gunes et al., 2007; Crusciol et al., 2009; Mauad et al., 2016). Carvalho Junior et al. (2014) studied Barbados nuts treated with Si under salinity and identified changes in the number of leaves and leaf area, but no effect on overall plant growth. Increased resistance to multiple biotic and abiotic stressors in plants treated with $\mathrm{Si}$ has yet to be fully elucidated.

The use of silicates in agriculture has been identified as an important tool in the expression of genes for tolerance to abiotic stresses, particularly water deficit. The development of consistent research can validate the recommendation of this innovative management technique by making regions prone to low water availability suitable for the cultivation of commercial species. Thus, it is important to identify and substantiate the role of silicon in tolerance to water deficit. The aim of this study was to evaluate the effect of silicate fertilization on the growth of Jatropha curcas L. seedlings submitted to water deficit.

\section{Results and Discussion}

Summaries of analyses of variance and tests to compare the means of plants with and without silicon for the variables: biomass, stem diameter, number of leaves, leaf area, relative water content in the leaf, root mass ratio, leaf mass ratio, leaf chlorophyll $a+b$ content, carotenoids and transpiration are shown in Tables 1 and 2. Treatment with silicon caused no changes in any of the variables studied and interaction between silicon treatment and the volume of water applied was only evident for the variables stem diameter and transpiration. The beneficial effects of $\mathrm{Si}$ have been demonstrated in several plant species, particularly those submitted to biotic and/or abiotic stressors (Ma et al., 2016; Teodoro et al., 2013). However, in the present study Si showed no beneficial effects in Barbados nut plants. Moreover, it is important to underscore that the element did not minimize the effects of drought stress and the drought tolerance exhibited by Jatropha curcas is independent of $\mathrm{Si}$ supply, as discussed below. Water availability directly affected plant growth. Regardless of $\mathrm{Si}$ dose, biomass accumulation, number of leaves, stem diameter and leaf area exhibited a linear decline proportional to the decrease in water supply.

The regression curves for the growth variables biomass, leaf number, stem diameter and leaf area are shown in Fig. 1. Regardless of Si treatments, biomass, number of leaves, stem diameter and leaf area declined linearly as water availability decreased. Plants treated with $\mathrm{Si}$ and untreated plants showed similar results, with no statistical significance observed. Only stem diameter showed a correlation between treatment with silicon and the volume of water applied, with both curves increasing and very similar. Regression curves for the variables transpiration, leaf carotenoid content, root and leaf mass ratio are shown in Fig. 2. Leaf transpiration and the leaf area index exhibited a significant linear decrease with the decline in water availability, whereas leaf carotenoid content and root mass ratio increased with reduced water availability. Only leaf transpiration displayed interaction between treatment with silicon and the volume of applied water. In general, Si-treated plants showed similar results to untreated plants, albeit with no statistical difference.

The reduction in the leaf mass ratio, number of leaves and leaf area occurs because water is needed to initiate and expand leaf primordia. The high stomatal sensitivity of Jatropha curcas combined with the reduced biomass partitioned to the leaves contributed to decreasing transpiration and maintaining water status. Among the morphological changes observed during drought stress, the reduced size and smaller number of leaves were the most significant (Santana et al., 2011; Souza et al., 2015; DiazLópez et al., 2012). Despite the difference in volume of water supplied in the treatments, relative water content showed no variation and Shy regression fit with clear dehydration delay signals. According to Matos et al. (2014), delayed dehydration is the primary drought tolerance strategy of Barbados nut plants. Reduced transpiration in plants subject to drought stress is associated with high stomatal sensitivity and less biomass partitioning to the leaves. Low transpiration enables sufficient hydration for plant metabolism and growth (Matos et al., 2016).

High stomatal sensitivity and reduced transpiration may have occurred in parallel to the low $\mathrm{CO}_{2}$ assimilation rate and resulting decline in biomass accumulation in plants subject to drought stress. However, continued hydration and reduced growth in the aerial parts were necessary for root growth and the allocation of assimilates to the root system. Greater root growth raises the soil volume used and increases the likelihood of the root system's reaching wet conditions, an important mechanism in drought tolerance (Diaz-López et al., 2012; Matos et al., 2014).

Delayed dehydration ensures plant tissue is hydrated enough for the synthesis of photosynthetic pigments, particularly carotenoid. The highest concentration of this pigment in plants irrigated with low water volume may be associated with photoprotection mechanism of the species, for this condition of reduced stomatal opening is a common occurrence of photoinhibition of photosynthesis and oxidative stress. Carotenoids are powerful pigments active in plant photoprotection, including deleted reactive species.

Si-treated and untreated plants showed similar results; however, in this study the element did not minimize drought damage. Nevertheless, the reduced transpiration rate in fully irrigated Si-treated plants in plants with $\mathrm{Si}$ under full irrigation may indicate that this mineral element exert important action on water status, albeit at different concentrations from those used in this experiment. Low transpiration in plants treated with silicon due to the formation of a silicon-cuticle double layer has been reported in the literature (Bukhari et al., 2015; Carvalho Junior et al., 2014.) This layer may have formed in the ground Si-treated Barbados nut plants, partially explaining the low transpiration rate observed. Most $\mathrm{Si}$ is incorporated into the cell wall and leaf surface and may have interfered in the production of epicuticular wax, thereby minimizing transpiration and contributing to reduced absorption and greater reflection of sunlight. According to Oliveira et al. (2003) and Salatino et al. (1998), epicuticular wax plays a vital role in reducing transpiration and acts as a deterrent to leafcutter ants, given the increase in reflected sunlight. 
Table 1. Summary of the analysis of variance and testing for biomass (BIO), stem diameter (SD), number of leaves (NL), leaf area (LA) and relative water content in the leaf (RWC) of Jatropha curcas plants submitted the different levels of evapotranspiration (Evap) combined with foliar application of silicon $(\mathrm{Si})$.

\begin{tabular}{|c|c|c|c|c|c|c|}
\hline \multirow[b]{2}{*}{ Variation source } & \multirow[b]{2}{*}{ DF } & \multicolumn{5}{|c|}{ Mean squares } \\
\hline & & $\begin{array}{c}\mathrm{BIO} \\
(\mathrm{g})\end{array}$ & $\begin{array}{l}\text { SD } \\
(\mathrm{cm})\end{array}$ & NL & $\begin{array}{c}\text { LA } \\
\left(\mathrm{cm}^{2}\right)\end{array}$ & $\begin{array}{c}\text { RWC } \\
(\%)\end{array}$ \\
\hline $\mathrm{Si}$ & 1 & $34.54^{\mathrm{ns}}$ & $1.08^{\mathrm{ns}}$ & $48.40^{\mathrm{ns}}$ & $280.47^{\mathrm{ns}}$ & $356.67^{\text {ns }}$ \\
\hline Evap. & 4 & $1018.28 * *$ & $34.08 * *$ & $780.77 * *$ & $50991.73 * *$ & $110.34^{\mathrm{ns}}$ \\
\hline Si x Evap. & 4 & $78.98^{\mathrm{ns}}$ & $6.77 *$ & $68.40^{\mathrm{ns}}$ & $4192.21^{\mathrm{ns}}$ & $280.13^{\text {ns }}$ \\
\hline Residue & 30 & 139.06 & 1.82 & 40.66 & 2060.73 & 311.94 \\
\hline $\mathrm{CV}(\%)$ & & $25.36 \%$ & $5.49 \%$ & $23.10 \%$ & $20.34 \%$ & $23.50 \%$ \\
\hline Treatments & & & & Averages & & \\
\hline Without Si & & $47.43 \mathrm{a}$ & $24.44 \mathrm{a}$ & $28.70 \mathrm{a}$ & $226.00 \mathrm{a}$ & $72.76 \mathrm{a}$ \\
\hline With Si & & $45.58 \mathrm{a}$ & $24.77 \mathrm{a}$ & $26.50 \mathrm{a}$ & $220.71 \mathrm{a}$ & $78.14 \mathrm{a}$ \\
\hline
\end{tabular}

$*$ significant at $5 \%$ and at $* * 1 \%$ probability; $\mathrm{ns}=$ not significant according to the $\mathrm{F}$ test. Means followed by the same lower case letter in the column do not differ at $5 \%$ probability according to the Newman-Keuls test.
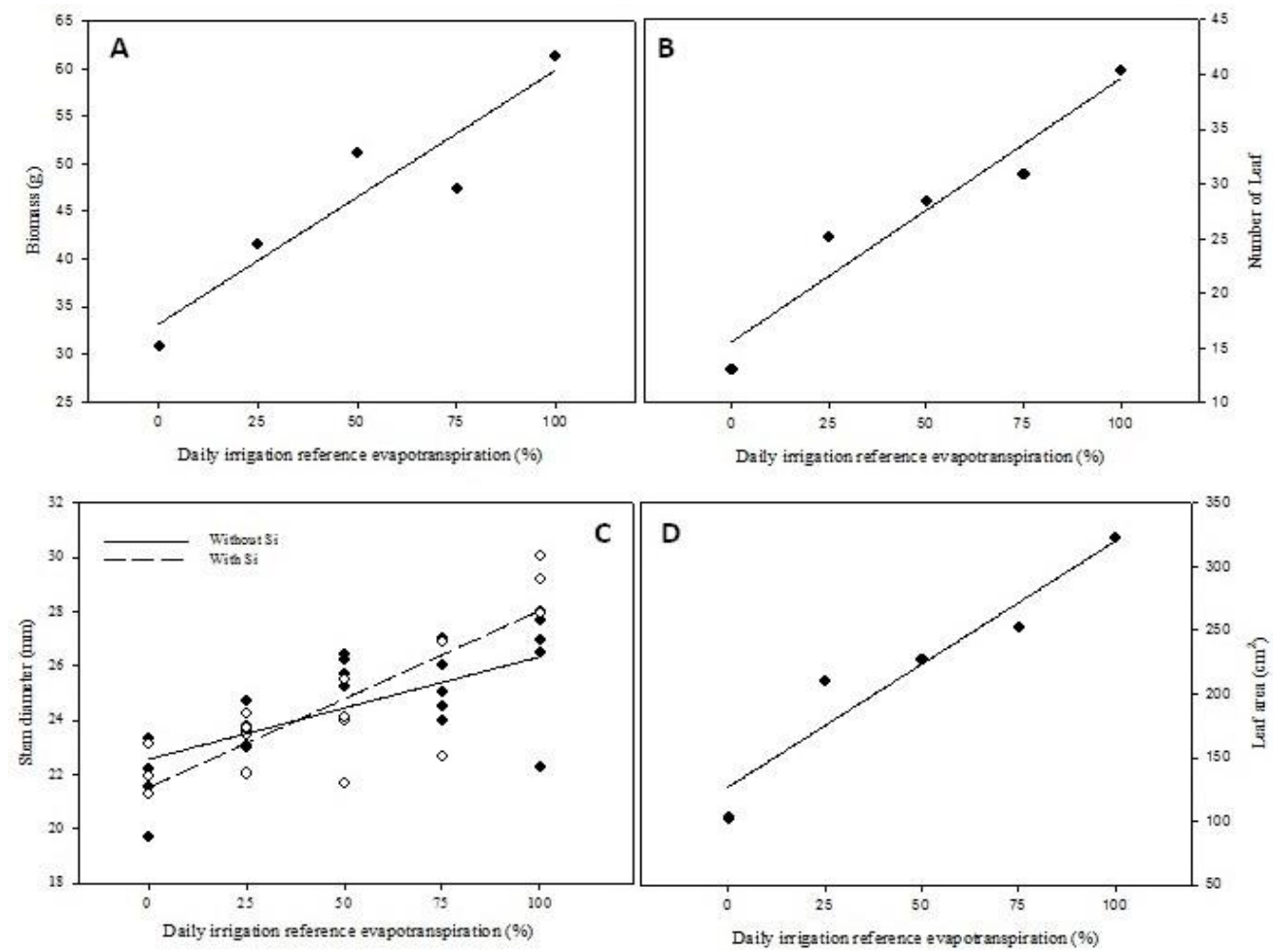

Fig 1. Regression equations for biomass " $A$ " $\left[Y 1=33.18+0.267 x, R^{2}=0.99 * *\right.$ number of leaves "B" $\left[Y 1=15.55+0.241 x, R^{2}=0.99 * *\right.$, stem diameter "C" [Y1= 22.56-0.038x, R ${ }^{2}=0.99 * *$ with $\mathrm{Si}$; $\mathrm{Y} 2=21.52-0.065 \mathrm{x}, \mathrm{R}^{2}=0.99^{*}$ without $\left.\mathrm{Si}\right]$ leaf area "D" [Y1= $126.91+1.93 \mathrm{x}, \mathrm{R}^{2}=0.99 * *$ of Jatropha curcas plants irrigated water volumes corresponding to $0 \%, 25 \%, 50 \%, 75 \%$ and $100 \%$ of evapotranspiration and fertilized with 0 and $1 \mathrm{~g} \mathrm{~L}^{-1}$ of $\mathrm{Si}$. *significant at $5 \%$ probability; **significant at $1 \%$ probability according to the F- test.

Table 2. Summary of analysis of variance and testing for root mass ratio (RMR), leaf mass ratio (LMR), leaf content of chlorophyll $a+b(\mathrm{Chl} a+b)$, carotenoids (CAR) and transpiration (E) of Jatropha curcas plants submitted different levels of evapotranspiration (Evap) combined with foliar application of silicon (Si).

\begin{tabular}{|c|c|c|c|c|c|c|}
\hline \multirow[b]{2}{*}{ Variation source } & \multirow[b]{2}{*}{ DF } & \multicolumn{5}{|c|}{ Mean squares } \\
\hline & & RMR & LMR & $\begin{array}{c}\text { Chl }(\mathrm{a}+\mathrm{b}) \\
\left(\mathrm{g} \mathrm{Kg}^{-1}\right)\end{array}$ & $\begin{array}{c}\text { CAR } \\
\left(\mathrm{g} \mathrm{Kg}^{-1}\right)\end{array}$ & $E\left(\mathrm{~g} \mathrm{H}_{2} 0 \mathrm{dia}^{-1}\right)$ \\
\hline $\mathrm{Si}$ & 1 & $0.00^{\mathrm{ns}}$ & $0.00^{\mathrm{ns}}$ & $0.02^{\mathrm{ns}}$ & $0.00^{\mathrm{ns}}$ & $2402.50^{\mathrm{ns}}$ \\
\hline Si x Evap. & 4 & $0.00^{\mathrm{ns}}$ & $0.00^{\mathrm{ns}}$ & $0.94^{\mathrm{ns}}$ & $0.01^{\mathrm{ns}}$ & $13521.25 * *$ \\
\hline Residue & 30 & 0.00 & 0.00 & 0.41 & 0.00 & 3036.75 \\
\hline CV (\%) & & $15.78 \%$ & $26.82 \%$ & $27.52 \%$ & $11.87 \%$ & $33.10 \%$ \\
\hline Without Si & & $0.13 \mathrm{a}$ & $0.23 \mathrm{a}$ & $2.31 \mathrm{a}$ & $0.72 \mathrm{a}$ & $158.75 \mathrm{a}$ \\
\hline With Si & & $0.13 \mathrm{a}$ & $0.24 \mathrm{a}$ & $2.37 \mathrm{a}$ & $0.70 \mathrm{a}$ & $174.25 \mathrm{a}$ \\
\hline
\end{tabular}

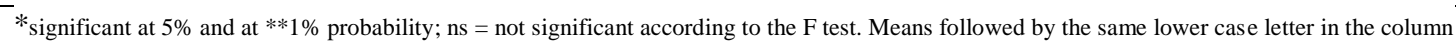
do not differ at $5 \%$ probability according to the Newman-Keuls test. 

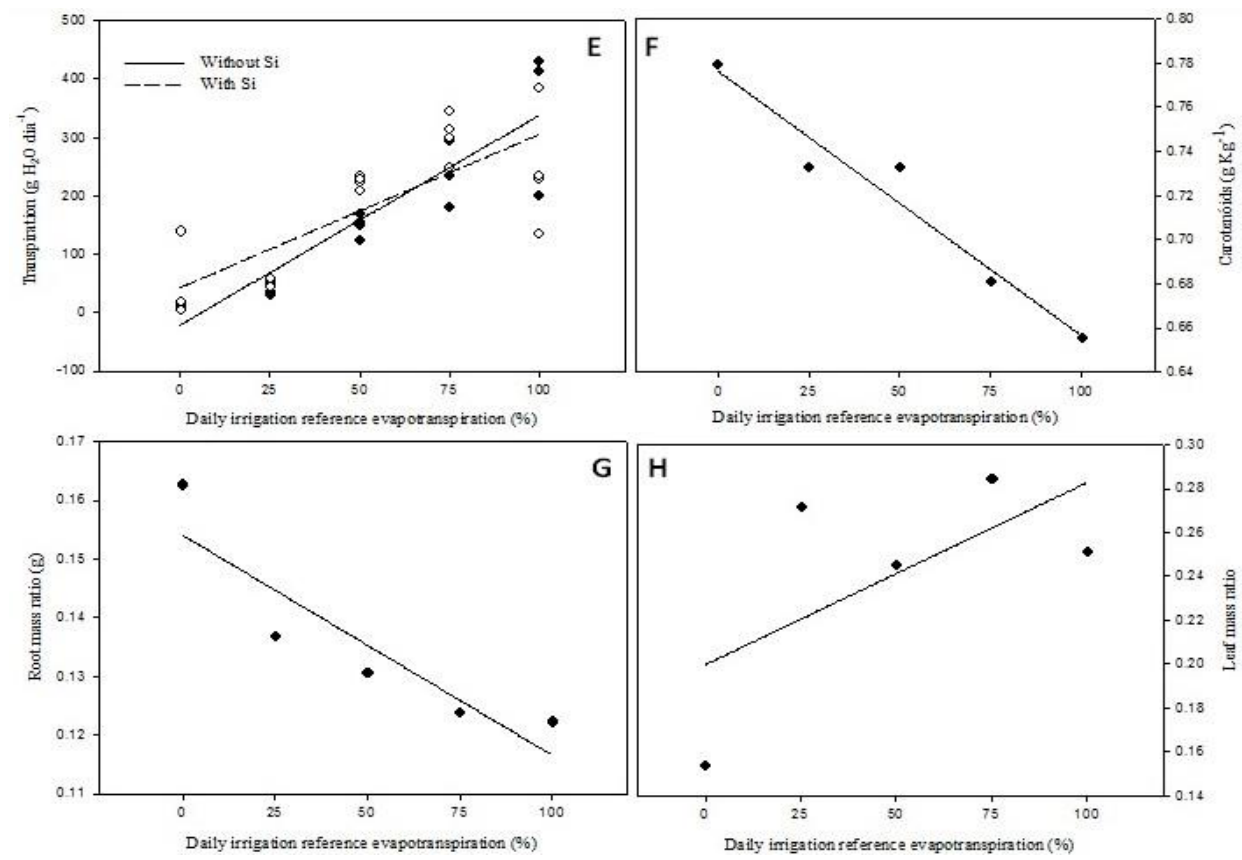

Fig 2. Regression equations for transpiration " $E$ " $\left[Y 1=-20.75+3.59 x, R^{2}=0.93 * *\right.$ with $\mathrm{Si}$; $Y 2=43.25+2.62 x, R^{2}=0.88 * *$ without $\mathrm{Si}$, carotenoids " $\mathrm{F"}$ ( $\left.\mathrm{Y} 1=0.78-0.0012 \mathrm{x}, \mathrm{R}^{2}=0.99 * *\right)$, root mass ratio " $\mathrm{G}$ " $\left[\mathrm{Y} 1=0.15+0.0003 \mathrm{x}, \mathrm{R}^{2}=0.93 *\right.$ and leaf mass ratio " $\mathrm{H}$ " ( $\left.\mathrm{Y} 1=0.20-0.0008 \mathrm{x}, \mathrm{R}^{2}=0.99 * *\right)$, of Jatropha curcas plants irrigated water volumes corresponding to $0 \%, 25 \%, 50 \%, 75 \%$ and $100 \%$ of evapotranspiration and fertilized with 0 and $1 \mathrm{~g} \mathrm{~L}^{-1}$ of Si. *significant at $5 \%$ probability; **significant at $1 \%$ probability according to the F-test.

\section{Materials and Methods}

\section{Plant materials}

The experiment was conducted in a greenhouse with a transparent plastic roof and 50\% shade cloth sides (Sombrite $\left.{ }^{\circledR}\right)$ at the State University of Goiás, Ipameri Campus (Lat. 170 43' 19"' S, Long. 480 09' 35"' W, elevation $773 \mathrm{~m}$ ), in Ipameri, Goiás. The region has a wet tropical climate (Aw), according to Köppen's classification system, with a rainy summer and dry winter. A completely randomized $5 \times 2$ factorial design was applied (plants irrigated every day with a water volume corresponding to $0,25,50,75$ and $100 \%$ evapotranspiration and foliar feeding of $\mathrm{Si}$ at concentrations of 0 and $1 \mathrm{~g} \mathrm{~L}^{-1}$, applied on April 29 and May 6,2016 , in a volume of $30 \mathrm{ml} / \mathrm{plant} /$ application), with four repetitions and one plant per pot. Since the crop coefficient (kc) for Jatropha curcas has yet to be determined for the Ipameri region (GO), a kc of 1.00 was applied in accordance with the FAO-56 estimate (Allen et al., 1998) for a group of crops in the initial growth stage. The volume of water provided was estimated based on the reference evapotranspiration and crop coefficient. Crop evapotranspiration was determined using the equation:

$\mathrm{ETc}=\mathrm{ETo} \mathrm{x} \mathrm{kc}$

Where:

$\mathrm{ETc}=$ crop evapotranspiration

$\mathrm{kc}=$ crop coefficient

$\mathrm{ETo}=$ Reference evapotranspiration

Daily ETo was calculated by the FAO Penman-Monteith method (Smith et al., 1991) using the daily data on minimum and maximum temperature, relative humidity, solar radiation and wind speed obtained from the INMET Weather Station located in the municipality of Ipameri, GO.
Drought stress treatment was imposed on April 29, 2016, when the plants were 60 days old, and lasted 13 days. Next, the following parameters were analyzed: plant height, stem diameter, number of leaves, leaf area, total transpiration, relative water content, electrolyte leakage, photosynthetic pigments, root, stem and leaf mass ratios, root length and total biomass.

\section{Growth and physiological variables}

The number of leaves were counted and leaf area was calculated by measuring the length and width of all the leaves, in line with the recommendations of Severino et al. (2006). Root diameter and length were measured using a digital caliper and graduated ruler. For destructive testing, the roots, stems and leaves were separated and dried in an oven at $72^{\circ} \mathrm{C}$ until constant dry weight and then weighed. The dry weight data were used to calculate the root mass ratio (RMR), stem mass ratio (SMR), leaf mass ratio (LMR) and total biomass. Total daily plant transpiration was determined by the difference in weight of the pots. First, each pot was placed inside a plastic bag attached to the stem of the plant with a rubber band, leaving only the aerial parts (stem and leaves) exposed. Next, the pot (and bag) was weighed at $12 \mathrm{pm}$ (weight 1) and then again 24 hours later (weight 2). Total transpiration was estimated based on the difference between weight 1 and 2 .

In order to calculate relative water content, ten $14 \mathrm{~mm}$-wide leaf discs were collected, weighed and immersed in distilled water for $8 \mathrm{~h}$ in Petri dishes. Next, the discs were weighed and dried at $70^{\circ} \mathrm{C}$ for 72 hours. The membrane permeability of leaf tissue was assessed using an adaptation of the methodology described by Vasquez-Tello et al. (1990) and Pimentel et al. (2002). In each repetition 15 leaf discs were collected from fully expanded leaves and submerged in 30 $\mathrm{mL}$ of distilled water in amber glass bottles for 24 hours, at room temperature, in the dark. After this period, conductivity 
(SC, $\mu \mathrm{S} / \mathrm{cm}$ ) was measured using a CD-880 handheld conductivity meter. Next, the bottles were placed in an oven for 1 hour at $100{ }^{\circ} \mathrm{C}$ and total conductivity was measured (TC, $\mu \mathrm{S} / \mathrm{cm}$ ). The results obtained were used to calculate the electrolyte release rate.

In order to determine chlorophyll and carotenoid content, three leaf discs (14 $\mathrm{mm}$ in diameter) with a known leaf area were collected, placed in a mortar with a pinch of $\mathrm{CaCO}_{3}$ and sand containing around $5 \mathrm{~mL}$ of $80 \%$ acetone and ground under green light. The extract was filtered directly into a 25 $\mathrm{mL}$ balloon covered with aluminum foil and the volume was completed with acetone solution. Aliquots were removed for spectrophotometric readings at 470, 646.8 and $663.2 \mathrm{~nm}$. Chlorophyll $a(\mathrm{Chl} a)$, chlorophyll $b(\mathrm{Chl} b)$ and chlorophyll $a+b(\mathrm{Cl} a+b)$ concentrations were determined according to Lichthenthaler, (1987).

\section{Statistical analysis}

Statistical analyses used a completely randomized $5 \times 2$ factorial design with four repetitions. Differences between the treatment means were analyzed using Newman Keuls test at $5 \%$ probability. Linear and quadratic regression analyses were also conducted and the coefficient of determination was obtained by dividing the regression sum of squares by the treatment sum of squares. All statistical analyses were performed using SISVAR software (Ferreira, 2011).

\section{Conclusion}

The Si doses used in this study did not minimize the effects of drought in Jatropha curcas plants. Jatropha curcas plants are drought tolerant, capable of delaying tissue dehydration and partitioning assimilates for root growth, as well as increasing leaf carotenoid content.

\section{Acknowledgments}

The authors are grateful to FAPEG and UEG for the financial assistance and technical support.

\section{References}

Allen RG, Pereira LS, Raes D, Smith M (1998) Crop evapotranspiration: guidelines for computing crop water requirements. Rome: FAO, 300p. (FAO. Irrigation and Dranaige Paper, 56).

Agencia Nacional de Óleo, Gas e Biodiesel (ANP) available in <http://www.anp.gov.br. Acess on: April 10, 2016.

Bukhari MA, Ashraf MY, Ahmad R, Waraich, E. A.; Hameed, M (2015) Improving drought tolerance potential in wheat (Triticum aestivum L.) through exogenous silicon supply. Pakistan J Bot. 47(5): 1641-1648.

Carvalho Junior GS, Rocha LMS, Rocha MS, Beltrão NEM, Negreiros KV (2014) Crescimento do pinhão-manso sob diferentes níveis de salinidade e silício. Rev Caatinga. 27(4): 39-46.

Carvalho HM, Ribeiro AB (2012) Biodiesel: Vantagens e desvantagens numa comparação com o diesel convencional. Bolsista de Valor. 2(1): 49-54.

Crusciol CAC, Pulz AL, Lemos LB, Soratto RP, Lima GPP (2009) Effects of silicon and drought stress on tuber yield and leaf biochemical characteristics in potato. Crop sci. 49 (3): 949-954.
Dehgan B, Webster GL (1979) Morphology and infrageneric relationships of the genus Jatropha (Euphorbiaceae). Univ of California Press. 74: 1-73.

Diaz-López LD, Gimeno V, Lidón V, Simón I, Martínez V, Sánchez FG (2012) The tolerance of Jatropha curcas seedlings to $\mathrm{NaCl}$ : Aneco physiologic analysis. Plant Physiol Biochem. 54(2): 34-42.

FAO (2010) Food and Agriculture Organization of the United Nations Jatropha a Smallholder Bioenergy Crop. The Potential for Pro-Poor Development; FAO, Integrated Crop Management: Rome, Italy. 8: 1-114.

Ferreira FA (2015) Avaliação Da Toxicidade e do Potencial Angiogênico do Látex de Pinhão Manso. (Master thesis) Programa de pós-graduação em Produção Vegetal Universidade Estadual de Goiás. 1-46.

Ferreira DF (2011) Sisvar: A computer statistical analysis system. Ciência e Agrotec. 35(6): 1039-1042.

Gong H, Zhu X, Chen K, Wang S, Zhang C (2005) Silicon alleviates oxidative damage of wheat plants in pots under drought. Plant Sci. 169: 313-321.

Gunes A, Inal A, Bagci EG, Coban S (2007) Influence of silicon on antioxidant mechanisms and lipid peroxidation in chickpea (Cicer arietinum L.) cultivars under drought stress. J Plant Interac. 2(2): 105-113.

Lichthenthale HK (1987) Chlorophylls end carotenoids: Pigments of photosynthetic bio membranes. In: Colowick SP, Kaplan NO (ed) Methods in Enzimilogy. Academic Press, San Diego. 148: 350-382.

Ma JF, Miyake Y, Takahashi E (2001) Silicon as a benefic element for crop plants. In: Datnoff LE, Snyder GH, Korndörfer GH (Eds.) Silicon in agriculture. Amsterdam: Elsevier. 17-39.

Matos FS (2010) Caracterização Fisiológica da Senescência Foliar de Populações de Jatropha curcas L. (Doctor thesis) - Universidade Federal de Viçosa, Viçosa, MG. 1-48.

Matos FS, Torres Junior HD, Rosa VR, Santos PGF, Borges LFO, Ribeiro RP, Neves TG, Cruvinel CKL (2014) Estratégia morfofisiológica de tolerância ao déficit hídrico de mudas de pinhão manso. Magistra. 26: 19-27.

Matos FS, Oliveira PRC, Gil JLRA, Sousa PV, Gonçalves GA, Sousa MPBL, Silveira PS, Silva LM (2016) Eucalyptus urocan drought tolerance mechanisms. Afr J Agric R. 11(18): 1617-1622.

Mauad M, Crusciol CAC, Nascente AS, Grassi Filho, H, Lima GPP (2016) Effects of silicon and drought stress on biochemical characteristics of leaves of upland rice cultivars. Rev Ciência Agronômica. 47(3): 532-539.

Nwvgo CC, Huerta AJ (2008) Effects of silicon nutrition on calmium uptake, growh and photosynthesis of Rice plants exposed to low-level cadmium. Plant Soil, Dodrecht. 311: 73-86.

Oliveira AFM, Meirelles ST, Salantino A (2003) Epicuticular waxes from caatinga and cerrado species and their efficiency against water loss. An da Acad Bras Cienc. 75(4): 431-439.

Openshaw K (2000) A review of Jatropha curcas: an oil plant of unfulfilled promise. Biomass and Bioenergy. 19(1): 1-15.

Pimentel C, Sarr B, Diouf O, Abboud ACS, Roy-Macauley H (2002) Tolerância protoplasmática foliar à seca, em dois genótipos de caupi cultivados em campo. Revista Universidade Rural, Série Ciências da Vida. 22: 07-14. 
Salantino A, Sugayama RL, Negri G, Vilegas W (1998) Effects of constituents of the foliar wax of Dimimopanax vlnosum on the foraging activity of the leaf-cutting ant Atta sexdens rubropilosa Entomol Exp Appl. 86: 261-266.

Santana MJ, Carvalho JA, Silva EL, Miguel DS (2011) Efeito da irrigação com água salina em um solo cultivado com o feijoeiro (Phaseolus vulgaris L.). Cienc. e Agrot. 27: 443450.

Severino LS, Vale LS, Beltrão NEM (2006) Método para medição da área foliar do pinhão manso. Rev Bras Ol Fib. 14: 73-77.

Souza BR, Freitas IAS, Lopes VA, Rosa VR, Matos FS (2015) Growth of Eucalyptus plants irrigated with saline water. Afr J Agric R. 10: 1091-1096.
Smith M (1991) Report on the expert consultation on revision of FAO methodologies for crop water requiremebts. Rome FAO. 1-45.

Teodoro PE, Ribeiro LP, Corrêa CCG, Torres FE (2013) Performance of hybrids of corn with leaf aplication of silicion in the savana sul-mato-grossense. Biosc J. 30(3): 224-231.

Vasquez-Tello A, Zuily-Fodil AY, Pham Thi T, Silva VJ (1990) Electrolyte and Pi leakages and soluble sugar content as physiological tests for screening resistance to water stress in Phaseolus and Vigna species. J Exp Bot. 41: 827-32. 